DedikasiMU (Journal of Community Service)

Volume 3, Nomor 3, September 2021

\title{
EDUKASI COVID-19 MELALUI PROGRAM KKN DAN MENGOPTIMALKAN UMKM DIDESA IKER-IKER DENGAN MENINGKATKAN PENJUALAN PRODUK MELALUI MEDIA ONLINE DIERA NEW NORMAL
}

\author{
Sukaris $^{1}$, Andi Rahmad Rahim ${ }^{2}$, Ernawati $^{3}$, Arya Setya Nugroho ${ }^{4}$, Anita Handayani ${ }^{5}$ \\ ${ }^{1,5}$ Dosen Manajemen, Universitas Muhammadiyah Gresik \\ ${ }^{2}$ Dosen Budidaya Perikanan, Universitas Muhammadiyah Gresik \\ ${ }^{3}$ Dosen Ilmu Keperawatan, Universitas Muhammadiyah Gresik \\ ${ }^{4}$ Dosen Program Studi PGSD, Universitas Muhammadiyah Gresik \\ Email: sidiqadhimbashori@gmail.com
}

\begin{abstract}
ABSTRAK
Corona virus Disease-2019 (COVID-19) diketahui menyebabkan infeksi saluran nafas pada manusia mulai dari batuk pilek. Persebaran virus COVID-19 meningkat semakin cepat melalui tetesan air liur atau keluar dari hidung ketika orang yang terinfeksi batuk atau bersin. Akan tetapi, masih sangat minim pemahaman dan kesadaran masyarakat di RT 02 Rw 01 Desa Ikeriker Kecamatan Cerme Kabupaten Gresik yang mematuhi protokol kesehatan saat beraktivitas di luar rumah. Lokasi tersebut merupakan padat penduduk. Oleh karena itu, perlunya peningkatan pemahaman COVID-19 dan pentingnya mematuhi protokol kesehatan penanggulangan COVID-19. Berdasakan permasalahan tersebut, penulis melakukan pengabdian pada masyarakat melalui kegiatan Kuliah Kerja Nyata (KKN) UMG Era Covid-19. Kegiatan yang dilakukan dengan metode Edukasi COVID-19 Kepada Masyarakat RT 02 RW 01 Desa Kedungwinangun. Pada program KKN ini dilakukan pembuatan handsanitizer, masker, dan disinfektanserta edukasi protokol kesehatan di lingkungan Rt 01 Rw 03 Desa Iker-iker. Telah berhasil dibuat dan disalurkan sebanyak 80 botol handsanitizer, 1 banner edukasi.
\end{abstract}

Kata Kunci: KKN, edukasi, COVID-19. 


\section{DedikasiMU (Journal of Community Service)}

Volume 3, Nomor 3, September 2021

\section{PENDAHULUAN}

\section{A. Latar Belakang}

Desa ini sangat dekat dengan pusat kecamatan Cerme. Desa yang mempunyai nama sederhana ini biasa disebut Desa Iker-Iker. Daerah yang dilalui jalur utama Cerme ini berbatasan dengan Desa Cerme Kidul, Betiting, Boboh, dan Morowudi. Berikut cerita penamaan desa tersebut. Desa ini memiliki 4 dusun, yaitu Iker-Iker, Jurit, Geger Wetan (Timur), Geger Kulon (Barat). Salah satu dusun dari desa ini adalah Jurit tempat berdirinya sekolah ternama yakni SMKN 1 Cerme. Iker-iker berasal dari Eker-eker yang berarti kekacauan, atau berantakan sedangkan Geger sendiri mempunyai arti perkelahian. Geger dibedakan menjadi 2 yaitu Geger Kulon dan Wetan.

Dahulu kala, ada penjajah yang mau menjajah desa Iker Iker Geger. Sebelum para penjajah tiba di desa itu. Warga desa sudah melakukan antisipasi jika para penjajah datang. Mereka mengumpulkan prajurit-prajurit yang akan menyerang penjajah. Para prajurit itu berkumpul di suatu alas yang sekarang menjadi Dusun Jurit.

Saat para prajurit sedang melakukan aktivitas persiapan untuk melawan penjajah, datanglah seorang yang sakti bin hebat tapi dia selalu membuat ulah. Dia selalu mengganggu warga yang tinggal di dusun yang sekarang dinamakan dusun Geger. Dia selalu membuat garagara di situ. Dia mendapat julukan dari warga sekitar Si Macan. Warga kesal akan tingkah laku Si Macan tapi warga takut untuk melawan. Si Macan selalu memberantakkan, membuat kekacauan yang sekarang memiliki nama dusun Iker-Iker yang berawal dari "eker-eker" (berantakan).

Cukup lama para warga memendam rasa ingin untuk melawan Si Macan. Akhirnya tercapai juga keinginan itu, mereka bersama-sama melawan Si Macan dan Si Macan pun terkalahkan. Jasad Si Macan dimakamkan di bawah jembatan yang sekarang nama jembatannya yaitu “Jembatan Macan Mati” yaitu tempat Si Macan mati. Yang juga menjadi perbatasan antara desa Iker-Iker Geger dengan desa Cerme Kidul.

Sebagian besar masyarakatnya mempunyai tambak yang cukup luas untuk budidaya ikan, salah satunya dimanfaatkan dengan membibit ikan mujair, ikan lele, dan lain lain. Di Desa Iker-iker menunjukkan bahwa mayoritas sudah mampu menyelesaikan sekolah dijenjang sekolah wajib belajar 12 tahun yaitu SD, SMP dan SMA atau sederajat. Didalam Desa Ikeriker sendiri hanya terdapat 2 lembaga pendidikan yaitu TK dan SD. 


\section{DedikasiMU (Journal of Community Service)}

Volume 3, Nomor 3, September 2021

Dalam pandemi Covid-19 ini mencakup banyak kerugian bagi masyarakat khusunya di desa Iker-iker, pemerintah telah melakukan berbagai upaya dalam menanggulangi penyebaran COVID-19, penambahan kasus positif COVID-19 di Indonesia semakin bertambah. Hal ini disebabkan karena kurangnya pengetahuan terhadap pandemi yang berimplikasi terhadap minimnya kesadaran masyarakat sehingga penanganan (pencegahan bagi yang tidak terinfeksi dan atau pengobatan terhadap yang terkena wabah) kurang terintegrasi-interkoneksi dalam sistem pemerintahan di negara kita. Dari pusat sampai bagian paling bawah, yaitu desa (kampung).Hal ini sangat berbahaya karena penyebaran COVID-19 sangat rentan tertular melalui mata, hidung, dan mulut (WHO, 2020).

Dengan melihat situasi RT 02 RW 01 Desa Iker-iker Kecamatan Cerme Kabupaten Gresik, kami melakukan kegiatan pengabdian kepada masyarakat dalam bentuk kegiatan Kuliah Kerja Nyata (KKN) UMG Era COVID-19 dengan tema Pencegahan COVID-19 “Untuk mewujudkan Kehidupan Baru (New Normal)”. Kegiatan KKN (Kuliah Kerja Nyata) dengan melakukan edukasi pemahaman, berkontribusi memberikan APD (Alat Pelindung Diri) pada pelaksanaan KKN dan penanggulangan COVID-19 melalui protokol kesehatan yang ada.

Berdasarkan latar belakang masalah diatas, KKN dengan melakukan edukasi di masyarakat RT 02 RW 01 Desa Iker-iker Kecamatan Cerme Kabupaten Gresik, dalam melakukan penanggulangan COVID-19 melalui program edukasi pencegahan penyebaran dan penularan COVID-19. Dalam mencegah penularan dan penyebaran COVID-19 ini, saya memberikan Handsanitizer pada masyarakat melalui perwakilan masyarakat ketua RT dan memasang banner dengan tujuan untuk memberi kesadaran pada masyarakat akan peduli pada COVID -19, pentingnya memakai handsanitizer saat berada di luar rumah dan pentingnya mematuhi protocol kesehatan. 


\section{DedikasiMU (Journal of Community Service)}

Volume 3, Nomor 3, September 2021

\section{METODE PELAKSANAAN}

\section{A. Onlineisasi dan Oflineisasi (Melalui pemilik UMKM dan ketua RT)}

Menyampaikan maksud dan tujuan kegiatan dalam bentuk Kegiatan Penyuluhan dari ketua RT ke RT dan memberikan edukasi pada pemilik UMKM. Kegiatan tersebut ditujukan pada RT dan UMKM di Desa Iker-iker.

Masyarakat diberikan motivasi agar memiliki kemauan untuk menggunakan tenaga dalam kegiatan mencegah covid 19. Selain itu, pemilik UMKM diberikan edukasi materi tentang menjual produk sarung tenun melalui media online lewat aplikasi "OLX" bertujuan agar penjualan semakin meningkat diera pandemi COVID -19 ini.

\section{B. Perencanaan Kegiatan}

Perencanaan kegiatan dapat dilakukan setelah pelaksanaan onlineisasi dan offlineisasi dilakukan, tetapi terlebih dahulu perlu melakukan survey terhadap seluruh warga yang ada di sekitar desa Iker-iker, dengan melihat apakah angka penularan covid 19 semakin naik setiap hari, setiap minggu, bahkan setiap bulan.

Agar program ini berjalan secara maksimal, maka diperlukan perencanaan secara tepat, diantaranya:

a. Mengamati pentingnya mengadakan program karena latar belakang warga menerapkan pentingnya tenaga kerja usaha dimasa pandemi saat ini.

b. Menyusun waktu pelaksanaan kegiatan

c. Mempersiapkan perlengkapan dalam memberikan APD (Alat Pelindung Diri)

d. Melakukan penyaluran handsanitizer warga yang terdampak covid 19

\section{C.Pelaksanaan}

a. Mahasiswa menyiapkan sarana prasarana dan peralatan yang digunakan dalam pendampingan pembuatan dan pelaporan warga.

b. Mahasiswa melakukan edukasi terhadap UMKM upaya penjualan di media online

c. Mahasiswa memberikan kebutuhan untuk protokol kesehatan dengan handsanitizer jumlah yang banyak. 


\section{DedikasiMU (Journal of Community Service)}

Volume 3, Nomor 3, September 2021

\section{Teknik Pelaksanaan}

Pelaksanaan kegiatan pengabdian dengan cara pemberdayaan kepada masyarakat ini dilakukan dengan menggunakan metode, planning, place, promotion dan diskusi. Adapun sisi mandiri dari pelaksanaan kegiatan pemberdayaan ini adalah sebagi berikut:

\section{Langkah 1 (Metode Planning):}

Berguna agar semua yang diperlukan telah siap dan dapat langsung memulai pengerjaan tanpa adanya suatu kekurangan, karena telah disiapkan dari jauh sebelumnya.

\section{Langkah 2 (Metode Place)}

Tempat dan lokasi sangat penting untuk mengetahui seberapa banyak dan seberapa besar tempat bisa mencukupi bagi pembuatan handsanitizer.

\section{Langkah 3 (Metode Promotion)}

Lewat metode promosi ini agar barang yang kita jual tidak sepi pembeli dan tetap meramaikan jenis produk yang dipasarkan.

\section{HASIL DAN PEMBAHASAN}

\section{A. Edukasi}

Pada KKN ini edukasi berfokus pada masyarakat RT 02 RW 01 Desa Iker-iker Kecamatan Cerme Kabupaten Gresik. Edukasi yang dilakukan tetap menerapkan sistem social distancing yaitu sosialisasi menggunakan sosial media, banner. Sosialisai berfokus pada penggunaan alat protokol kesehatan yaitu masker dan handsanitizer. Berikut merupakan edukasi yang dilakukan:

\section{a. Edukasi COVID-19 melalui Banner}

Pada bulan Juli 2020, pemerintah melarang warganya untuk berkerumunan demi pencegahan penularan covid-19. Dalam rangka mendukung program New Normal, saya memberikan edukasi covid-19 melalui banner yang dipasang di Balai Desa Iker-iker. 


\section{DedikasiMU (Journal of Community Service)}

Volume 3, Nomor 3, September 2021

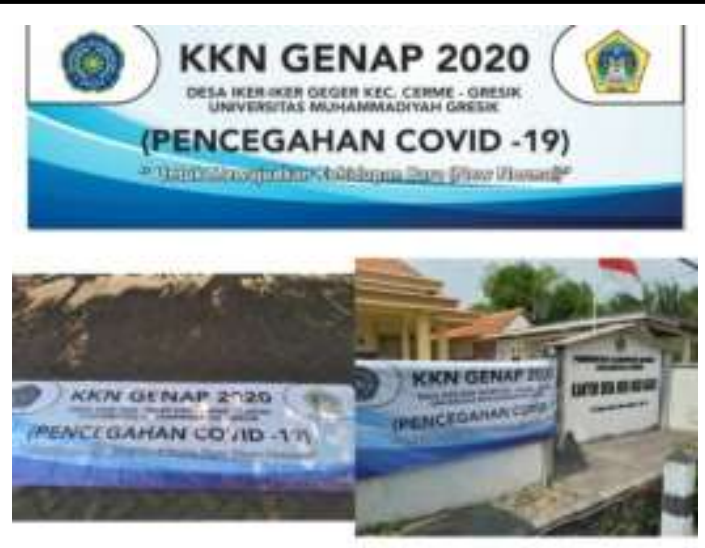

Gambar 1. Sosialisasi Kegiatan

\section{b. Edukasi COVID-19 melalui Sosial Media}

Dengan menyebarkan edukasi penjualan diera pandemi covid-19 melalui media sosial. Tujuannya tentu terutama demi menyebarluaskan pengetahuan tentang penjualan dengan promosi secara online. Adapun media sosial yang digunakan adalah Whatsapp.

\section{c. Edukasi Penyaluran Handsanitizer}

Penggunaan handsanitizer merupakan salah satu upaya pencegahan covid-19. Di tengah pandemi covid-19, handzanitizer sangat diperlukan jika masyarakat akan berpergian. Dengan begitu kami melakukan penyaluran handsanitizer ke perwakilan warga/ketua RT.

\section{KESIMPULAN DAN SARAN}

\section{A. Kesimpulan}

Kegiatan KKN di desa Iker Iker kecamatan cerme kabupaten Gresik dilaksanakan selama kurang lebih 29 hari (27 Juli -24 Agustus 2020). Program KKN saya ini memberikan edukasi atau pengetahuan tentang cara pencegahan dengan menghindari faktor-faktor yang bisa menyebabkan infeksi terjadinya covid 19. Selain itu saya juga memberikan edukasi kepada pelaku UMKM akan pentingnya mengembangkan produk yang telah dibuatnya melalui media online. Sebagai bentuk peningkatan pemahaman penanggulangan COVID-19 di RT 02 RW 01 Desa Iker-iker telah dilakukan edukasi melalui media online, banner, dan stiker. Edukasi dengan sistem tersebut dilakukan sebagai salah satu bentuk penerapan protokol work from home dan social distancing. Edukasi dimaksudkan agar masyarakat paham mengenai pentingnya pengguaan protokol kesehatan saat melakukan aktivitas di luar rumah. 


\section{DedikasiMU (Journal of Community Service)}

Volume 3, Nomor 3, September 2021

\section{B. Saran}

Diharapkan dengan dibagikannya handsanitizer dan banner warga desa iker-iker dapat dalam membantu menjaga kesehatan dan apabila keluar rumah tetap mematuhi protokol kesehatan.

\section{DAFTAR PUSTAKA}

Al Fatina, A., Rochma, N. A., Salsabilah, N., Sari, C. S., Rahma, A., Fauziyah, N., Sukaris, S \& Rahim, A. R. (2021). Pemberdayaan Para Pemuda Dalam Pemanfaatan Tanaman Obat Keluarga (Toga) Temulawak (Curcuma Xanthorhiza) Menjadi Olahan Ice Cream Di Desa Sambogunung. DedikasiMU (Journal of Community Service), 3(2), 801-810.

Al Fatina, A., Rochma, N. A., Salsabilah, N., Eprilyanto, A. F., Aulia, R., Sukaris, S., Fauziyah, N \& Rahim, A. R. (2021). Pembuatan Minyak Sereh Dan Lilin Aromaterapi Sebagai Anti Nyamuk. DedikasiMU (Journal of Community Service), 3(2), 837-847.

WHO. (2020) 'WHO announces COVID-19 outbreak a pandemic' World Health Organzation Regional Office for Europe.

https://www.majalah-alasjurit.com/2016/11/asal-usul-desa-iker-iker-cerme.html?m=1 